\title{
Determination of water quality at Orwell International Oil and Gas Nigeria limited, Rivers State, Nigeria
}

\author{
Nte Felix. U. ${ }^{1}$, Esi Emmanuel O. ${ }^{2}$, Edomi O. ${ }^{2}$ \\ ${ }^{1}$ Department of Physics, University of Port Harcourt, Choba, Rivers State, Nigeria \\ ${ }^{2}$ Department of GNS (Physics unit), Delta State School of Marine Technology, Burutu, Delta State, Nigeria
}

Email address:

esiemmanuel@yahoo.com(Esi E.O)

\section{To cite this article:}

Nte Felix. U., Esi Emmanuel O., Edomi O.. Determination of Water Quality at Orwell International Oil and Gas Nigeria Limited, Rivers State, Nigeria. International Journal of Environmental Monitoring and Analysis. Vol. 1, No. 6, 2013, pp. 302-306. doi: $10.11648 /$ j.ijema.20130106.15

\begin{abstract}
Water is one of the abundantly available substances in nature. It is a vital factor for aquatic life as well as for human use. In this report, water samples were collected from Orwell International Oil and Gas Nigeria limited (both borehole water, drainage water and Cway water) all were analyzed for their major, minor and trace metals element constituents and physiochemical parameter, using modern analytical methods. The results were evaluated with a view to determine and compare the quality of the water sampled from the study area with WHO Standard to enable us knows the quality of water in the industrial layout. The following physiochemical and heavy metals were analyzed with concentration level range as follow: Total dissolved solid "TDS" ranged from $20.0-250 \mathrm{mg} / \mathrm{l}$ with mean value as $123.33 \mathrm{mg} / \mathrm{l}$ ), Total suspended solid "TSS" ranged from $12.0-130 \mathrm{mg} / \mathrm{l}$ with mean value as $51.33 \mathrm{mg} / \mathrm{l}$, Total hardness ranged from 8.0 $32.02 \mathrm{mg} / \mathrm{l}$ with mean value as $18.67 \mathrm{mg} / \mathrm{l}$, Conductivity ranged from $7.0-46.0 \mu \mathrm{s} / \mathrm{cm}$ with mean value as $26 \mu \mathrm{s} / \mathrm{cm}, \mathrm{pH}$ ranged from $4.21-7.21$ with mean value as 6.06, Dissolved oxygen "DO" ranged from $4.80-5.60 \mathrm{mg} / 1$ with mean value as $5.067 \mathrm{mg} / \mathrm{l}$, Biochemical Oxygen Demand "BOD" ranged from $15.0-30 \mathrm{mg} / \mathrm{l}$ with mean value as $20.833 \mathrm{mg} / \mathrm{l}$, Salinity ranged from $15.40-35.91 \mathrm{mg} / \mathrm{l}$ with mean value as $25.56 \mathrm{mg} / \mathrm{l}$, Iron "Fe" ranged from $0.088-3.396 \mathrm{mg} / 1$ with mean value as $1.21 \mathrm{mg} / \mathrm{l}, \mathrm{Pb}$ ranged from $0.014-0.047 \mathrm{mg} / \mathrm{l}$ with mean value as $0.0143 \mathrm{mg} / \mathrm{l}, \mathrm{Zn}$ ranged from $0.065-0.159 \mathrm{mg} / \mathrm{l}$ with mean value as $0.125 \mathrm{mg} / \mathrm{l}, \mathrm{Cd}$ ranged from $0.006-0.013 \mathrm{mg} / \mathrm{l}$ with mean value as $0.0006 \mathrm{mg} / \mathrm{l}$ and $\mathrm{Ni}$ ranged from $0.015-$ $0.140 \mathrm{mg} / \mathrm{l}$ with mean value as $0.0743 \mathrm{mg} / \mathrm{l}$. The mean values for TDS, TSS, Conductivity and Salinity were below the WHO Standard for portable drinking water, while the total hardness and dissolved oxygen falls within the WHO Standard limit. The BOD was above the WHO Compliance limit for portable drinking water, although the $\mathrm{pH}$ for the Cway water fall within the WHO permissible limit for portable water but the $\mathrm{pH}$ for borehole water is below the WHO permissible limit for portable water. The presence of some heavy metals $(\mathrm{Zn}, \mathrm{Pb}, \mathrm{Cd}, \mathrm{Fe}, \mathrm{Ni})$ were also detected in the analysis which will be toxic to human being and the environment at high concentration.
\end{abstract}

Keywords: Water Quality, Heavy Metals, Physiochemical Parameter, Standard, Environment

\section{Introduction}

Water quality is the physical, chemical and biological characteristics of water. It is most frequently used by reference to a set of standards against which compliance can be assessed (Hudson. et al, 2006). The most common standards used to assess water quality relate to drinking water, safety of human contact and for the health ecosystems. Protection of water source is a major environmental issue since the important of water quality on human health has attracted a great deal of interest lately (Christopher et al 2011). Clean, fresh drinking water is essential to human and other life forms. Access to safe drinking water has improved steadily and substantially over the decades in almost every part of the world (Bjorm, 2001). Water plays an important role in the world economy, as it functions as a solvent for a wide variety of chemical substance and facilitates, industrial cooling and transportation.

Determining water quality and developing strategies to protect water source from contamination are necessary for proper planning. Water pollution is mainly due to the process of industrialization and urbanization that has progressively developed over time without any regard for environmental consequences (Longe et al 2010), (Horsfall 
and Spiff 2001), (Sharman 2006).

It is expected that industrial effluents will contain some of these physiochemical substance and heavy metals in reasonable quantity. Discharge of these industrial effluents and sewage into natural water at increased concentration can have severe toxicological effect on aquatic environment and humans (DWAF, 1996). Many water resources in developing countries are unhealthy because they contain harmful physical chemical and biological agents (Adetunde et al, 2011). Large numbers of people in developing countries die annually as a result of water borne diseases such as Cholera, typhoid, hepatitis, diarrhea etc (WHO, 2008). Hence, care must be taken to protect water reservoir from irreparable harm through effective discharge of industrial effluent.

To maintain a good health however, water should be safe to drink and meet the local standard and international standards to taste, odour and appearance (Chessbrough, 2000). To monitor the water resource and ensure sustainability, national and international criteria and guideline established for water quality Standards are being used (WHO, 1993; 2005). Environmental protection agencies have emerged in recent time to help combat the threat of environmental pollution. Therefore, this study is aimed at evaluating the water quality in and around Orwell international Oil and Gas Nigeria Limited Trans Amadi Port-Harcourt.

\section{Material and Method}

Table. 1. The physio-chemical and heavy metals parameters of the water samples (borehole, drainage, CWAY water) from the Orwell international oil and gas Nigeria Limited.

\begin{tabular}{|c|c|c|c|c|c|}
\hline S/No & Parameters & $\begin{array}{c}\text { W.H.O } \\
\text { standard } \\
\end{array}$ & $\begin{array}{c}\text { Borehole water } \\
\text { sample }\end{array}$ & $\begin{array}{c}\text { Drainage water } \\
\text { sample }\end{array}$ & CWAY water sample \\
\hline 1. & TDS & 500 & $100.0 \mathrm{mg} / 1$ & $250.0 \mathrm{mg} / 1$ & $20.0 \mathrm{mg} / 1$ \\
\hline 2. & TSS & 500 & $12.0 \mathrm{mg} / \mathrm{l}$ & $130.0 \mathrm{mg} / \mathrm{l}$ & $12.0 \mathrm{mg} / \mathrm{l}$ \\
\hline 3. & TOTAL HARDNESS & $0-60$ & $16.0 \mathrm{mg} / 1$ & $32.02 \mathrm{mg} / 1$ & $8.0 \mathrm{mg} / \mathrm{l}$ \\
\hline 4. & CONDUCTIVITY & $50-500 \mu \mathrm{s} / \mathrm{cm}$ & $25 . \mu \mathrm{g} / \mathrm{cm}$ & $46.0 \mu \mathrm{g} / \mathrm{cm}$ & $7.0 \mu \mathrm{g} / \mathrm{cm}$ \\
\hline 5. & PH & $6.5-8.5$ & 4.21 & 7.21 & 6.75 \\
\hline 6. & DO & $3-7 \mathrm{mg} / 1$ & $5.60 \mathrm{mg} / 1$ & $4.80 \mathrm{mg} / 1$ & $4.80 \mathrm{mg} / 1$ \\
\hline 7. & $\mathrm{BOD}_{5}$ & $0.1-2$ & $17.5 \mathrm{mg} / 1$ & $30.0 \mathrm{mg} / 1$ & $15.0 \mathrm{mg} / 1$ \\
\hline 8. & SALINITY & 250 & $25.37 \mathrm{mg} / 1$ & $35.91 \mathrm{mg} / 1$ & $15.40 \mathrm{mg} / 1$ \\
\hline 9. & $\mathrm{Fe}$ & $0.01-0.3$ & $0.13 \mathrm{mg} / \mathrm{l}$ & $3.396 \mathrm{mg} / 1$ & $0.088 \mathrm{mg} / 1$ \\
\hline 10. & $\mathrm{~Pb}$ & $0.01 \mathrm{mg} / 1$ & $0.047 \mathrm{mg} / 1$ & $0.010 \mathrm{mg} / 1$ & $0.014 \mathrm{mg} / 1$ \\
\hline 11. & $\mathrm{Zn}$ & $3.0 \mathrm{mg} / 1$ & $0.159 \mathrm{mg} / \mathrm{l}$ & $0.151 \mathrm{mg} / 1$ & $0.065 \mathrm{mg} / 1$ \\
\hline 12. & $\mathrm{Cd}$ & $0.003 \mathrm{mg} / 1$ & $0.0013 \mathrm{mg} / 1$ & $0.009 \mathrm{mg} / \mathrm{l}$ & $0.006 \mathrm{mg} / 1$ \\
\hline 13. & $\mathrm{Ni}$ & $0.02 \mathrm{mg} / 1$ & $0.140 \mathrm{mg} / 1$ & $0.098 \mathrm{mg} / 1$ & $0.015 \mathrm{mg} / 1$ \\
\hline
\end{tabular}

The standard water sampling method was used in collecting the water samples for this study. A specific sampling site known as ORWELL INTERNATIONAL OIL and GAS NIGERIA LIMITED was chosen for the sample collection. The site is located at Trans Amadi industrial layout, Port-Harcourt on a bearing of 0408.6681 North and 007001.932 East.

Three water samples were collected. The water sources include: Orwell international oil and gas Nigeria Limited borehole water, drainage water and C.way bottle water. Samples were collected in thoroughly washed and sterilized two (2) liter plastic containers to avoid contamination of samples. Before taking the final water samples, the plastic containers were rinsed three times with the water to be sampled at the point of collection.

Collection of samples was carried out by filling the containers to the tip before closing to avoid bubbles trapped. The samples containers were then sealed with tight fitted corks, and were also correctly labeled. After collection, water sample containers were stored at room temperature throughout and transported to the laboratory for analysis. Water quality parameters analyzed in accordance to standard method were $\mathrm{pH}$ using $\mathrm{pH}$ meter, conductivity using conductivity meter, TSS, TDS, Total hardness, DO and BODs using filtration and gravimetry, salinity using digital meter. Heavy metals ( $\mathrm{Fe}, \mathrm{Pb}, \mathrm{Zn}, \mathrm{Cd}$ and $\mathrm{Ni}$ ) were also determined using the Scientific Atomic Absorption Spectrophotometer.

\section{Results and Discussion}


Table 2. The Mean Standard ( $\mu$ ) And Standard Deviation (S.D)

\begin{tabular}{ccc}
\hline PARAMETERS & MEAN $(\mathbf{X})$ & STANDARD DEVIATION S.D \\
\hline TDS & $123.33 \mathrm{mg} / 1$ & $123.33 \pm 116.762$ \\
TSS & $51.33 \mathrm{mg} / 1$ & $51.33 \pm 81.153$ \\
TOTAL HARDNESS & $18.67 \mathrm{mg} / 1$ & $18.64 \pm 12.24$ \\
CONDUCTIVITY & $26 \mu \mathrm{s} / \mathrm{cm}$ & $26 \pm 19.52$ \\
pH & 6.06 & $6.06 \pm 1.616$ \\
DO & $5.067 \mathrm{mg} / 1$ & $5.067 \pm 0.462$ \\
BOD5 & $20.833 \mathrm{mg} / 1$ & $20.833 \pm 8.0364$ \\
SALINITY & $25.56 \mathrm{mg} / 1$ & $25.56 \pm 10.256$ \\
Fe & $1.21 \mathrm{mg} / 1$ & $1.21 \pm 1.897$ \\
Pb & $0.0143 \mathrm{mg} / 1$ & $0.0143 \pm 0.031$ \\
Zn & $0.125 \mathrm{mg} / 1$ & $0.125 \pm 0.052$ \\
Cd & $0.00066 \mathrm{mg} / 1$ & $0.00066 \pm 0.012$ \\
Ni & $0.0743 \mathrm{mg} / 1$ & $0.0743 \pm 0.0802$ \\
\hline
\end{tabular}

Table 1 and 2 shows the result of analysis carried out on water samples gotten from Orwell International Oil and Gas Nigeria Limited, Port Harcourt Rivers State.

From the analysis carried out, it was observed that the total dissolved solid level in the water samples ranges from $20 \mathrm{mg} / 1-250 \mathrm{mg} / \mathrm{l}$, with mean value of $123.33 \mathrm{mg} / \mathrm{l}$ when compared with WHO standard limit for drinking water it is below WHO standard. The total dissolved solid for borehole water has $100 \mathrm{mg} / \mathrm{l}$, but CWAY bottle water and drainage water has $20 \mathrm{mg} / 1$ and $250 \mathrm{mg} / 1$ respectively. For the borehole water the total dissolved solid is very high, it therefore means that the borehole water needs to be treated before being ingested with food or used as drinking water source.

The total suspended solid values for both the CWAY bottled water and borehole water are $12 \mathrm{mg} / \mathrm{l}$ which is normal, while the drainage water has as much as $130.0 \mathrm{mg} / \mathrm{l}$ partially because the water was not drained out. But when compared with WHO standard limit for drinking water it is below WHO standard.

Total hardness ranged from $8.0-16 \mathrm{mg} / \mathrm{l}$ with mean value of $18.67 \mathrm{mg} / \mathrm{l}$, the W.H.O standard for total hardness ranged from $0-60 \mathrm{mg} / \mathrm{l}$, the value obtained from the analysis falls within the WHO standard for drinking water when compared.

Conductivity of the Orwell oil and gas borehole, CEWAY, and Drainage water ranges from 7.0-46 $\mu \mathrm{s} / \mathrm{cm}$, with mean value of $26 \mu \mathrm{s} / \mathrm{cm}$ which is below the permissible limit of WHO standard limit for portable drinking water.

The $\mathrm{pH}$ analysis shows that the borehole water has a $\mathrm{pH}$ of 4.21 which is acidic, the drainage water has a $\mathrm{pH}$ of 7.21 which is slightly basic, this may be as a result of industrial and oil exploration activities going on within the region. While the CEWAY bottled water has a $\mathrm{pH}$ of 6.75 which is within WHO limit, when compared to WHO limits of 6.5-

\section{5 for drinkable water.}

Dissolved oxygen levels in borehole water $5.60 \mathrm{mg} / \mathrm{l}$ are greater than that of drainage water and Cway water with values $4.80 \mathrm{mg} / 1$ respectively. And the mean value for dissolved oxygen is $5.067 \mathrm{mg} / \mathrm{l}$. The values of dissolved oxygen of the samples analyzes when compared with WHO standard falls within the WHO drinking water standard and the survival of aquatic organism which is $3-7 \mathrm{mg} / \mathrm{l}$. If more oxygen is consumed than is produced dissolved oxygen is also caused by fertilizer and manure run-off, streets lawn and farms.

The concentration of BOD5 values for borehole water, drainage water and Cway water are; $17.5 \mathrm{mg} / 1,30.0 \mathrm{mg} / \mathrm{l}$ and $15.0 \mathrm{mg} / \mathrm{l}$ respectively and the mean value for BOD5 is $20.833 \mathrm{mg} / \mathrm{l}$. All the water samples values are high compared to WHO standard with values ranged from 0.1 $\mathrm{mg} / \mathrm{l}-2.0 \mathrm{mg} / \mathrm{l}$, indicating a high level of organic pollution in Orwell's water hence require treatment before use. The BOD5 value with the range $0.1-2 \mathrm{mg} / \mathrm{l}$ are considered clean, $3 \mathrm{mg} / \mathrm{l}$ are considered fairly clean, $5 \mathrm{mg} / \mathrm{l}$ are considered definitely bad and polluted. The greater the BOD5 value, the higher the degree of pollution (Horsfall and Spiff 2001).

The salinity concentrations for the samples ranged from $15.40 \mathrm{mg} / \mathrm{l}-35.91 \mathrm{mg} / \mathrm{l}$ and the mean concentration value is $25.56 \mathrm{mg} / \mathrm{l}$ when compared with WHO standard of 250.0 $\mathrm{mg} / \mathrm{l}$, it falls below the W.H.O standard for drinking water.

The concentration of iron for borehole water, drainage water and Cway water are; $0.13 \mathrm{mg} / 1,3.396 \mathrm{mg} / \mathrm{l}$ and 0.088 $\mathrm{mg} / \mathrm{l}$ respectively and the mean value for iron $(\mathrm{Fe})$ is 1.21 $\mathrm{mg} / \mathrm{l}$. All the water samples concentration falls within W.H.O standard limit when compared expect the drainage water with $3.396 \mathrm{mg} / \mathrm{l}$ concentration which is above WHO standard limit. The high value of iron in the drainage water is a clear manifestation of presence of toxic waste in the water. 
Lead $(\mathrm{Pb})$ with concentrations for borehole water, drainage water and Cway water as $0.047 \mathrm{mg} / 1,0.010 \mathrm{mg} / \mathrm{l}$ and $0.014 \mathrm{mg} / 1$ respectively, Zinc $(\mathrm{Zn})$ with concentrations for borehole water, drainage water and Cway water as $0.159 \mathrm{mg} / \mathrm{l}, 0.151 \mathrm{mg} / \mathrm{l}$ and $0.065 \mathrm{mg} / \mathrm{l}$ respectively, Cadmium (Cd) as $0.013 \mathrm{mg} / 1,0.009 \mathrm{mg} / \mathrm{l}$ and $0.006 \mathrm{mg} / \mathrm{l}$ respectively and Nickel (Ni) as $0.140 \mathrm{mg} / \mathrm{l}, 0.098 \mathrm{mg} / \mathrm{l}$ and $0.015 \mathrm{mg} / 1$ respectively. The mean values of Lead $(\mathrm{Pb})$, zinc $(\mathrm{Zn})$, Cadmium $(\mathrm{Cd})$ and Nickel $(\mathrm{Ni})$ are $0.0143 \mathrm{mg} / \mathrm{l}$, $0.125 \mathrm{mg} / 1,0.00066 \mathrm{mg} / 1$ and $0.0743 \mathrm{mg} / 1 \mathrm{respectively,}$ when compared with W.H.O standard the heavy metals concentrations falls within the permissible limit of the standard.

\section{Conclusion}

The study under review is the determination of water quality of Orwell international oil and gas Nigeria Limited, located at Plot 53, Trans Amadi Industrial Layout, Port Harcourt. From the result obtained, it was observed that the CEWAY bottled water is within the W.H.O standard and advised for consumption, but the borehole water is highly acidic with the $\mathrm{pH}$ of 4.21 which is not within W.H.O permissible limit i.e. (6.5-8.5) for portable water. The study therefore recommends treatment of the borehole water before passing it out for consumers. This will help reduce some water borne disease like Typhoid fever, cholera e.t.c. Heavy metals and other water pollutants are given special consideration in monitoring activity to prevent massive toxicity and health of the consumers to avert effects which are the typical water contaminants.

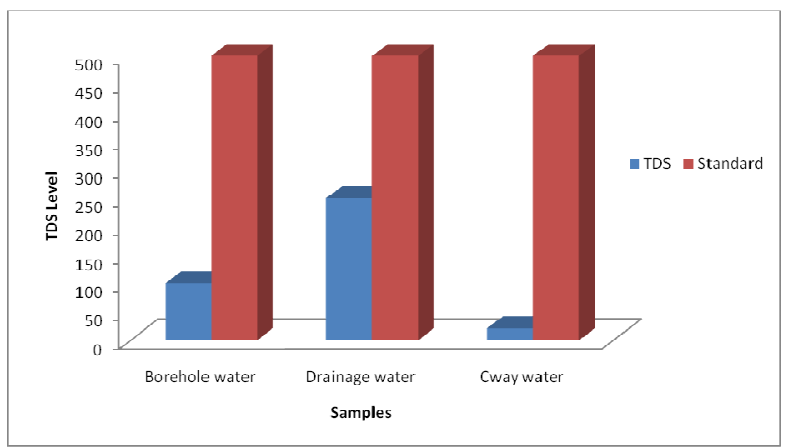

Fig 1. Comparison of TDS Concentration levels with standard

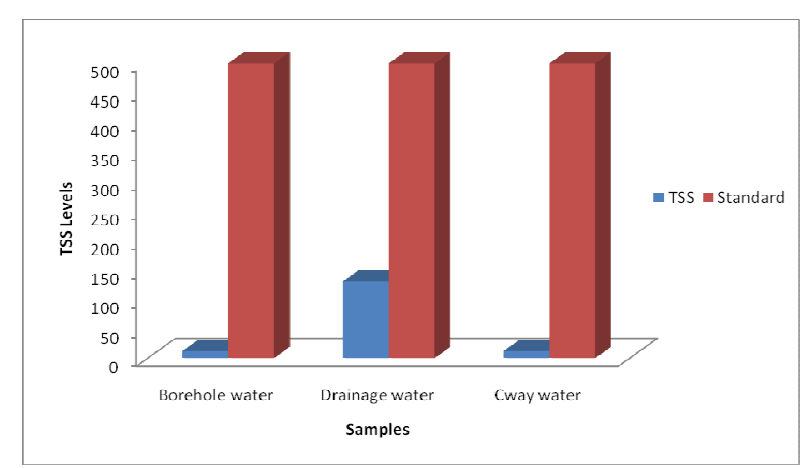

Fig 2. Comparison of TSS Concentration levels with standard

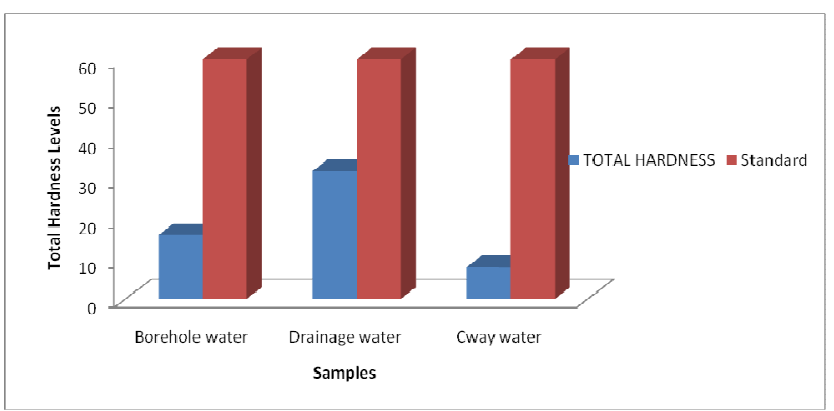

Fig 3. Comparison of Total Hardness Concentration levels with standard

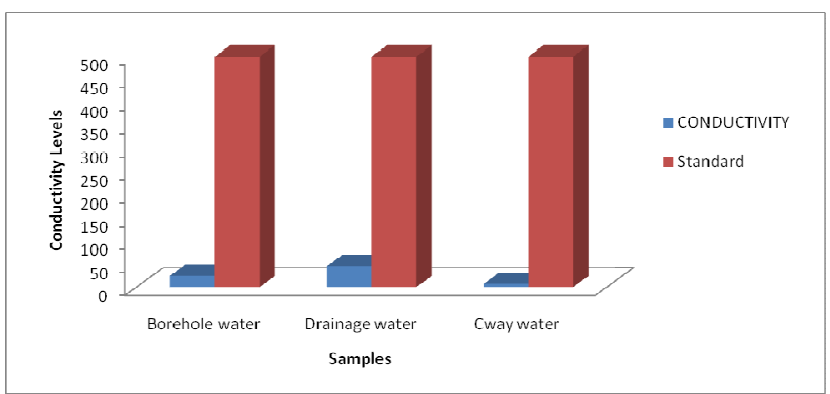

Fig 4. Comparison of Conductivity Concentration levels with standard

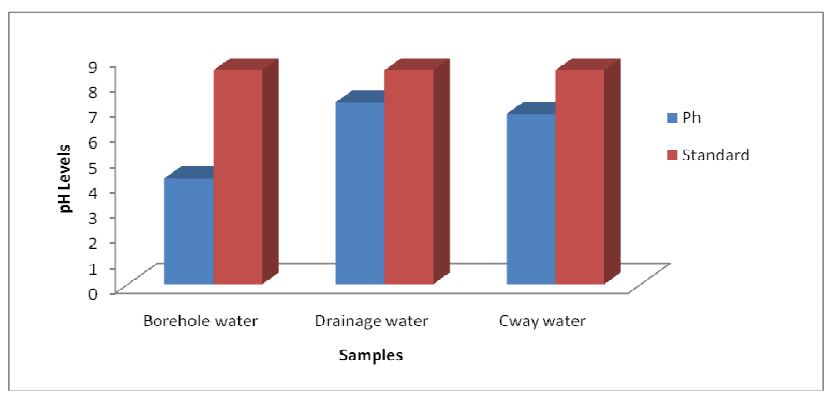

Fig 5. Comparison of Ph Concentration levels with standard

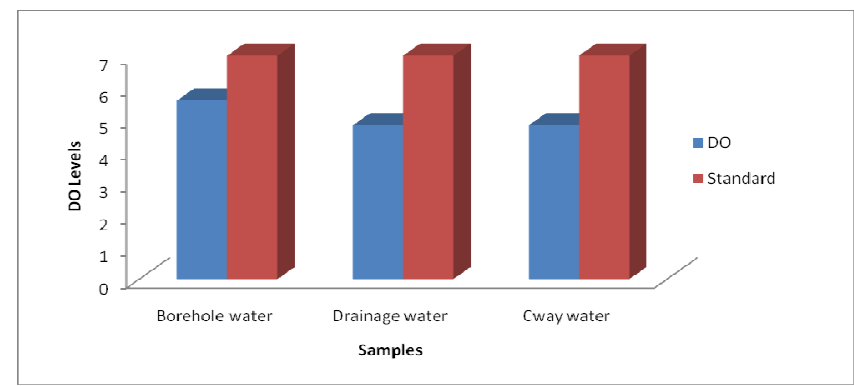

Fig 6. Comparison of DO Concentration levels with standard

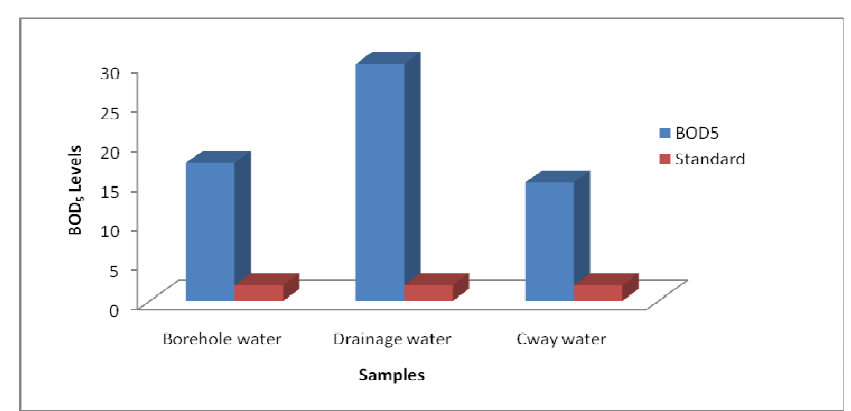

Fig 7. Comparison of $\mathrm{BOD}_{5}$ Concentration levels with standard 


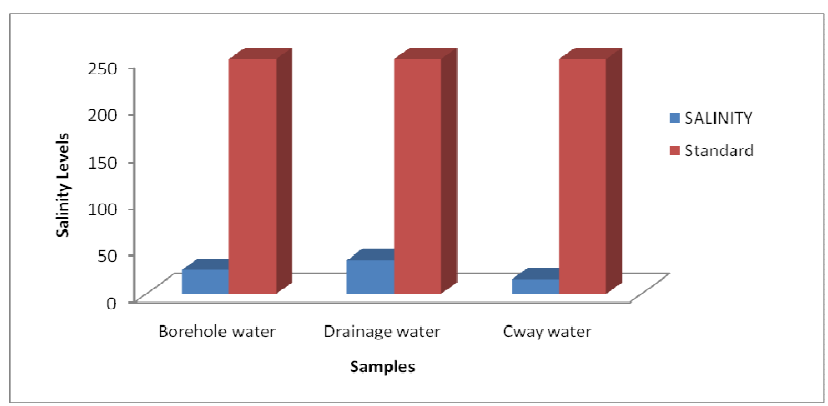

Fig 8. Comparison of Salinity Concentration levels with standard

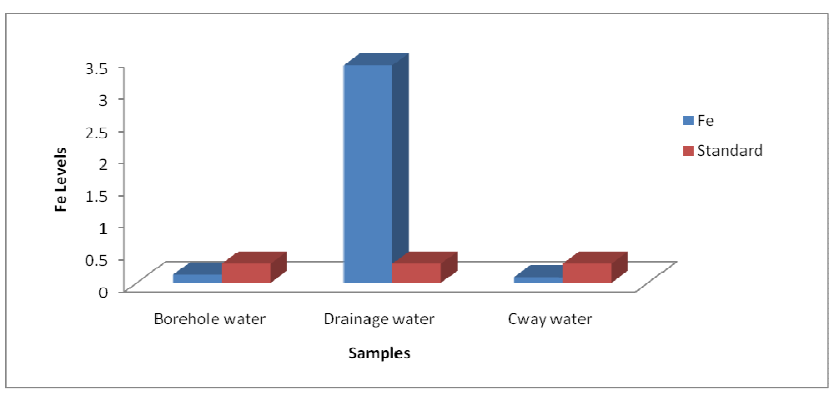

Fig 9. Comparison of Fe Concentration levels with standard

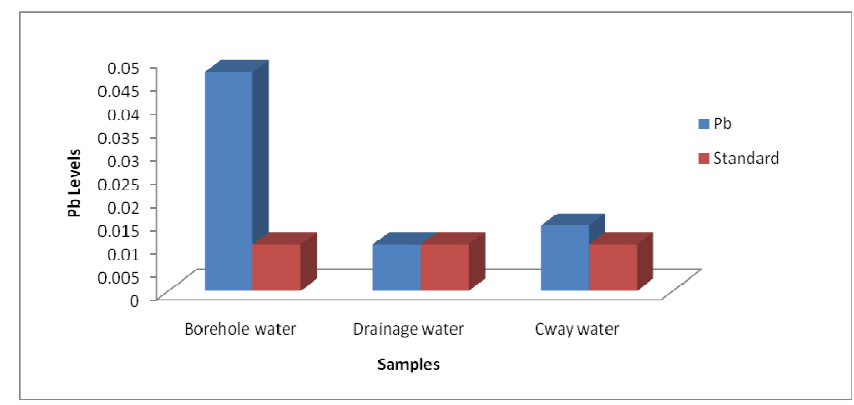

Fig 10. Comparison of Pb Concentration levels with standard

\section{References}

[1] Longe E. O and Balogun M.R, (2010) ;Groundwater Quality Assessment near a Municipal Landfill, Lagos, Nigeria; Research of Applied Sci. Eng'g and Technology 2(1) 93 - 44.

[2] Christopher .O. Akinbile and Molid .S. Yusoff (2011); Environmental Impact of Leachate pollution on Groundwater supplies in Akure, Nigeria; Intal journal of Environ. Sci. and Develop. 2 (1) $81-86$.

[3] Bjorm. I, (2001); The Skeptical Environmentalist Cambridge University Press. Pg 22.

[4] Hudson .K. and Manus L. A (2006); Drinking water quality framework for South Africa water S. A.

[5] Horsfall .M. Jr and Spiff A. I, (2001); Principle of Environmental Pollution. Meter print Ltd Nigeria

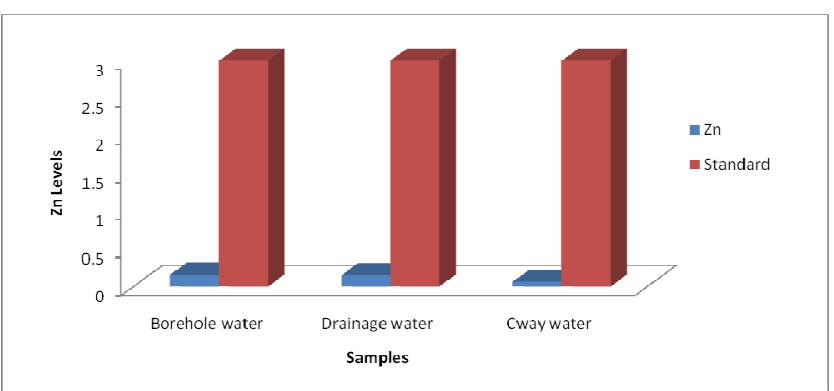

Fig 11. Comparison of Zn Concentration levels with standard

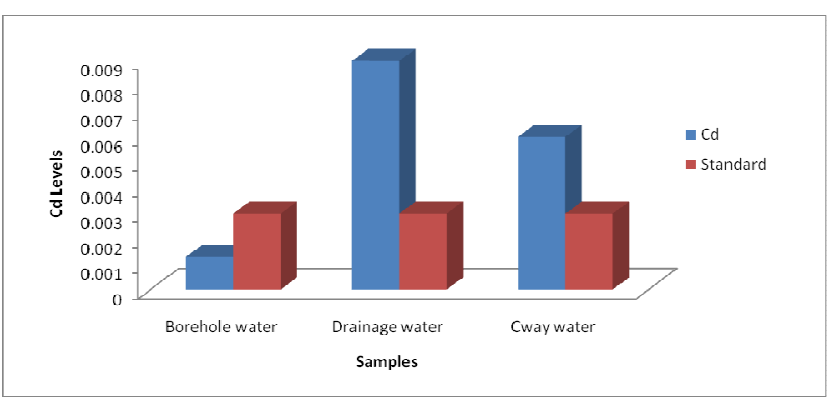

Fig 12. Comparison of $\mathrm{Cd}$ Concentration levels with standard

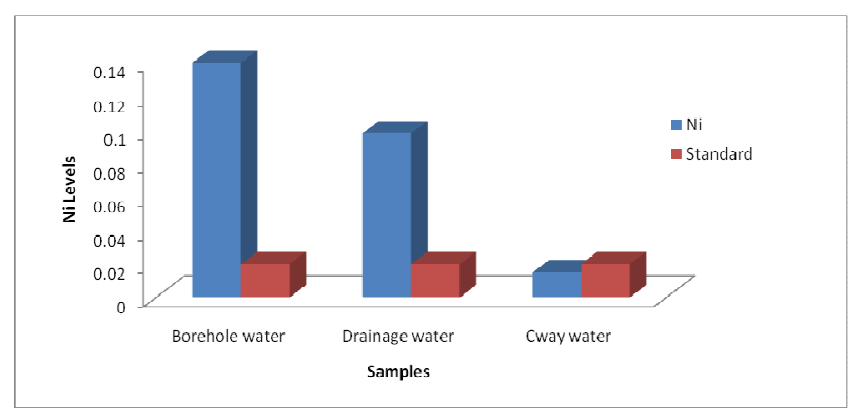

Fig 13. Comparison of Ni Concentration levels with standard

[6] Sharman B.K, (2006); Industrial Chemistry including Chemical Engineering goet publishing house meeting.

[7] DWAF, (1996); South Africa Water quality guideline, Aquatic ecosystem. Department of Water Affairs and Forestry Vol 7 (1).

[8] WHO, (2008); Sample water and global health. www.who/int/features/qa/70/en/index.html.

[9] Adetunde L.A et al, (2011); Assessment of the Groundwater quality in Ogbomoso township of Oyo State Nigeria. IJRRAS 8(1) 115 - 122.

[10] WHO (1993); Guidelines for Drinking water quality Vol (1) Recommendation. WHO Geneva Switzerland.

[11] WHO, (2005); Guidelines for Drinking water quality WHO, Geneva. Switzerland. 